\title{
A knowledge management framework to grow innovation capability maturity
}

\author{
Authors: \\ Denéle Esterhuizen ${ }^{1}$ \\ Corne Schutte ${ }^{1}$ \\ Adeline du Toit ${ }^{2}$ \\ Affiliations: \\ ${ }^{1}$ Department of Industrial \\ Engineering, University of \\ Stellenbosch, South Africa \\ ${ }^{2}$ Centre for Information and \\ Knowledge Management, \\ University of Johannesburg, \\ South Africa \\ Correspondence to: \\ Adeline du Toit \\ Email: \\ adutoit@uj.ac.za \\ Postal address: \\ PO Box 524, Auckland Park \\ 2006, South Africa \\ Dates: \\ Received: 12 Aug. 2011 \\ Accepted: 02 Apr. 2012 \\ Published: 30 May 2012 \\ How to cite this article: \\ Esterhuizen, D., Schutte, \\ C. \& Du Toit, A., 2012, 'A \\ knowledge management \\ framework to grow \\ innovation capability \\ maturity', SA Journal of \\ Information Management \\ 14(1), Art. \#495, 10 pages. \\ http://dx.doi.org/10.4102/ \\ sajim.v14i1.495
}

C 2012. The Authors. Licensee: AOSIS OpenJournals. This work is licensed under the Creative Commons Attribution License.
Background: Innovation is a key prerequisite for being organisationally competitive. Therefore, it is imperative that enterprises grow and mature their innovation capability. Knowledge management plays a fundamental role in the ability of enterprises to innovate successfully.

Objectives: There are no formal guidelines for using knowledge management to grow innovation capability maturity. The researchers intended to develop a knowledge management framework that enables innovation capability.

Method: The scope of the research did not allow for the practical implementation of the framework. However, five industry and subject theory experts evaluated the applicability and usability of the framework.

Results: All five experts reported that enterprises could use knowledge management tools and organisational facilitating conditions to allow innovation capability maturity to grow. The importance of the framework is that it gives guidelines for using knowledge management as a vehicle for growing innovation capability maturity.

Conclusion: The framework determines whether enterprises' organisational conditions and knowledge management tools are sufficient to sustain or grow their innovation capability maturity.

\section{Introduction}

Innovation is a key prerequisite for achieving organisational competitiveness and long-term wealth in the volatile business environment. Enterprises must be able to innovate, and do so constantly and sustainably, if they are to function competitively (Cavusgil, Calantone \& Zhao 2003; Moore 2005; Paap \& Katz 2007). The most common way of categorising for innovation is into two high-level categories: product and process innovation (Katz 2007). Neely, Filippini, Forza, Vinelli and Hii (2001) explain that product innovation involves developing and commercialising new tangible products or services. Process innovation involves:

- introducing new, or improving current, manufacturing, distribution and service processes

- any procedures or actions that enterprises introduce to transform resources associated with them.

Du Preez, Schutte, Essmann, Louw and Marais (2009) also emphasise that, with product innovation, all parties involved (the enterprises and their customers) should gain value from the transaction. They also argue that process innovation can relate to high-level managerial processes or to detailed sets of tasks to execute operational processes.

In addition to the product and process innovation categories, Baker (2002) highlights the importance of a third type of innovation: strategy innovation. He argues that product and process innovation alone are no longer adequate, necessitating the introduction of strategy innovation to provide further support. This type of innovation emphasises the importance of long-term views of the contributions of innovation to the competitiveness and success of enterprises. Hamel (2000) confirms this, referring to strategy innovation as business concept innovation (BCI).

$\mathrm{BCI}$ involves innovations to a variety of business design variables, including pricing structures, distribution channels and value webs or relationships. With innovation categorised into product, process and strategic innovations, it is necessary to add that a successful innovation is often a combination of the three types of innovations because new strategies can result in new products, which, in turn, require new processes (Du Preez et al. 2009).

Innovation makes it necessary to execute processes. One may show these processes as a life cycle of phases. Du Preez et al. (2009) describe a basic and generic representation of the innovation lifecycle that comprises the phases that follow: invention, feasibility, implementation, operation and disposal. Essmann (2009) points out that learning occurs in activities throughout all the 
innovation lifecycle phases. At the end of each phase, there are opportunities to learn from the successes and failures of that phase. One may revisit the innovation lifecycle phases in order to execute certain activities again or to refine certain aspects.

There are no known formal guidelines for using knowledge management to grow innovation capability maturity. Consequently, this article investigated how enterprises can use knowledge management tools to advance growth in innovation capability maturity. The question that it will address is whether enterprises can use knowledge management tools and organisational facilitating conditions to enable growth in innovation capability maturity.

\section{Capability maturity models}

Innovation capability is the way enterprises can generate innovative outputs. Essmann (2009) points out that enterprises must assess and improve their innovative capability to sustain, repeat and accelerate innovative initiatives. This requirement for assessment and constant improvement takes us directly to the concept of capability maturity models.

Generically, one can see capability maturity models as ways of deciding whether the processes enterprises use, as well as how they use them, characterise mature enterprises (Fairchild 2004). Capability maturity models are sets of structured levels that define how well the activities, practices and processes of enterprises can reliably and sustainably produce the outcomes they want. The two essential goals of capability maturity models are (Essmann 2009):

- to determine the capability maturity of enterprises in terms of a specific domain of practice

- to help to establish and guide improvement that will best suit the enterprises whilst complying with the prescribed best practices of the domain.

These points provide a platform for logical reasoning about the importance of capability maturity models. In order to understand the current position of enterprises compared to their competitors and to enterprises in other industries, it is necessary to establish its capability maturity in terms of a specific domain of practice. In addition, it is important for enterprises to benchmark themselves against the best or against those who are successful in order to determine how much, and in what direction, to improve. Although benchmarking is a recognised practice, it can present problems because most enterprises are reluctant to expose their competitive secrets.

The original Capability Maturity Model ${ }^{\circledR}$ for software (SW$\mathrm{CMM}^{\circledR}$ ) is a widely accepted set of guidelines for developing high-performance software enterprises (LeVasseur 2000). Watt Humphrey and colleagues at International Business Machines (IBM) developed the original concept behind SW-CMM ${ }^{\circledR}$ in the early 1980s. He placed the emphasis for improving software development on processes after establishing that the quality of software had a direct relationship with the quality of the processes used to develop it (LeVasseur 2000).

However, the Software Engineering Institute (SEI) of Carnegie Mellon University developed the original SW$\mathrm{CMM}^{\circledR}$ and first published it with the sponsorship of the United States Department of Defence (Cooke-Davies 2004). Most capability maturity models use the initial SW-CMM ${ }^{\circledast}$ of the SEI (Essmann 2009).

More recently, SEI developed Capability Maturity Model Integration ${ }^{\circledR}\left(\mathrm{CMMI}^{\circledR}\right)$. It is a model consolidated from the bodies of knowledge (or domains of practice) that follow: software development, systems engineering, integrated product and process development and supplier sourcing. Degen-Hientz, Fäustle \& Hörmann (2005) describe the $\mathrm{CMMI}^{\circledR}$ as a model and industry standard that contains best practices aimed at developing and maintaining products and services throughout their product lifecycles.

The concept of the capability maturity model, or the maturity model, has since spread to many organisational domains of practice. Champlin (2003) confirms this, stating that enterprises have a wide selection of capability maturity models from which to choose, not only between applications, but also within each application. There are capability maturity models for many applications, including software development, information technology (IT) management, project management, data management, business management and knowledge management. The total number of capability maturity models that were available in 2002 already exceeded 120

Most models have the same basic five-level maturity scale structure. The maturity level descriptions are often similar in the different models. ${ }^{1}$ The CMMI ${ }^{\circledR}$ Product Team (2002) defines a maturity level as a 'well-defined evolutionary plateau of process improvement'.

Enterprises do not necessarily start at maturity level 1. One benchmarks them against the capability maturity descriptions of each level and then assigns the appropriate level if they continue to fulfil the requirements the description for that level states. When one assigns a specific level, one also assumes that the enterprises have met the requirements for the previous levels. To reach maturity level 4 , for example, enterprises must have continuously fulfilled and institutionalised all the requirements of level 2, level 3 and level 4 . Level 1 is the launch pad for successive levels and does not imply that enterprises have met any maturity requirements.

Some recent and/or significant developments in innovation capability maturity models include:

- the Innovation Capability Maturity Model from Indutech (Essmann 2009)

- the Business Innovation Maturity Model from Accelper Consulting (2010)

1.This is possibly because the SW-CMM is the basis of most other capability maturity models. 
- the INPAQT Innovation Capability Maturity Model from INPAQT (2010)

- the Innovation Maturity Model from Tata Consultancy Services Ltd (Narayana 2005)

- the Innovation Maturity Model from OVO (2010)

- the Innovation Maturity Model from PRTM (2007)

- the Innovation Maturity Model from Think For A Change (2009)

- the Innovation Aptitude ${ }^{\mathrm{TM}}$ Audit from The Innovation Practice (2007).

Although enterprises use innovation capability maturity models in practice, there is insufficient information to distinguish between them. Furthermore, the theoretical and/or empirical foundations of these innovation capability maturity models are unclear, except for the Innovation Capability Maturity Model of Essmann (2009).

Essmann developed a model that describes a path for improving innovation capability maturity for competitively orientated enterprises. He did this using thorough academic research and practical case studies into the generic and fundamental requirements for organisational innovation capability. He then consolidated these generic and fundamental requirements for organisational innovation capability into his Innovation Capability Maturity Model (ICMM).

A description of the respective generic innovation capability maturity levels (with implied intermediate levels between level 1 and level 3 and between level 3 and level 5), as the ICMM specifies, follows. Examples of the innovation capability requirements include:

- Maturity level 1 - Ad hoc and limited: The innovationrelated practices and procedures are impromptu and limited in their ability to meet the requirements for consistent innovation.

- Maturity level 3 - Formalisation and predictability: Enterprises have identified and deployed innovationrelated best practices and procedures. This enables them to fulfil the requirements for innovation consistently. This does not imply that they must deploy rigid and stifling structures with which they must comply. Instead, they must use a proactive and planned approach to innovating.

- Maturity level 5 - Integration, synergy and autonomy: Once enterprises have achieved formalisation, institutionalising the practices follows - in other words, when activities become natural behaviour. This enables individual autonomy and releasing resources to concentrate on achieving alignment and synergy within and between innovation initiatives and with operational activities.

Essmann (2009) identified 42 essential requirements for organisational innovation capability. He structured these 42 innovation capability requirements within the model. Each has its own specific level 1, level 3 and level
5 maturity level scenario descriptions modelled on the generic maturity level descriptions:

- developing and conveying innovation strategies and objectives

- championing and encouraging innovation

- involving customers and suppliers in the innovation process

- planning and coordinating the innovation portfolio

- reducing uncertainty and risk

- establishing intellectual property management and sharing policies

- capturing, storing and retrieving data and information.

\section{Role of knowledge management in enabling growth in innovation capability maturity}

Gray (2000) states that knowledge management is best understood as the management practices associated with knowledge. Small and Sage (2005/2006) distinguish between two views of knowledge management. One approach focuses on knowledge resources to facilitate access and the reuse of existing explicit knowledge by using almost only information technology tools. The other approach is to treat knowledge management as a multidisciplinary subject that focuses on 'the context and environment for knowledge acquisition, representation, transformation, sharing, and use' (Small and Sage 2005/2006) using behavioural as well as technology management. Du Plessis (2007) argues that knowledge management must align with business strategies to improve enterprises' capability, tempo and effectiveness to deliver products or services through the planned and structured management of the 'creation, sharing, harvesting and leveraging of knowledge as an organizational asset' (Du Plessis 2007).

Davenport and Prusak (2000) point to the benefits of establishing knowledge cultures. They include better corporate alignment and unity, improved innovation through sharing, higher staff morale, increased responsiveness, decreased cycle times, reduced costs and increases in customer satisfaction. Successful knowledge management stimulates the development of creative skills, increases individual commitment, supports employees to outline task objectives systematically in networks that enable them to share knowledge with others and helps employees to determine their resource requirements. It also offers a platform for asking questions and providing innovative solutions (Carneiro 2000). Therefore, the literature provides a strong basis from which to argue that enterprises could use knowledge creation processes when investigating knowledge management guidelines for improving innovation capability maturity (Carneiro 2000; Cavusgil, Calantone \& Zhao 2003; Darroch 2005; Du Plessis 2007; Ruggles 1998).

However, the literature on how enterprises can use knowledge management tools and organisational facilitating conditions to enable growth in innovation capability maturity 
is sparse. At most, it implies that there is a relationship between knowledge management and enterprises' innovation capability maturity. Cavusgil et al (2003) investigated how firms acquire tacit knowledge from partners and how the extent of inter-firm knowledge transfer affects firm innovation capability. Calantone, Cavusgil and Zhao (2002) examined the concept of learning orientation and its effect on firm innovation capability.

Lin (2007) examined the influence of individual factors (enjoyment in helping others and knowledge self-efficacy), organisational factors (top support from managers and organisational rewards) and technology factors (information and communication technology use) on knowledge sharing processes and whether a presence of more of these factors leads to superior organisational innovation capability. This gap in the literature provides the platform for the work this article presents. However, the question of what this implies from a practical point of view remains.

When one evaluates the innovation capability maturity of enterprises, one benchmarks them against the requirements of the maturity level description of each innovation capability and assigns the appropriate level to them. Consequently, when enterprises grow in their innovation capability maturity, one measures them again against the requirements of each maturity level to determine whether their innovationrelated activities have improved to such an extent that one can assess them against a higher maturity level description.

However, this does not answer the question of how enterprises can use knowledge creation processes to help them improve their innovation-related activities in order to move from one maturity level description to a higher one.

The answer depends on enterprises' understanding of their key knowledge-related needs when they move to higher maturity levels. If one approaches it from a different angle, enterprises must decide what key knowledge actions (and the key knowledge creation processes) will enable them to move their innovation capability from one maturity level to the next.

In 1994, Nonaka presented two premises that shaped the development of organisational knowledge creation theory:

- one can distinguish tacit and explicit knowledge conceptually along a continuum

- knowledge conversion explains, theoretically and empirically, the interaction between tacit and explicit knowledge.

Nonaka's theory of knowledge creation has 'achieved paradigmatic status since the mid-1990s ... and is highly respected' (Gourlay 2006). Choo and Bontis (2002) described it as 'one of the best known and most influential models in the knowledge strategy literature'. They stated that Nonaka's knowledge creation model 'provides the intellectual scaffolding for a growing number of empirical and theoretical studies in strategic knowledge management'. Gourlay (2006) points out that the annual increase in the number of citations, as well as the range of categories of journals that have cited this publication, indicate a level of interest that make his research very important.

Nonaka's well-known socialisation, externalisation, combination and internalisation (SECI) model describes how enterprises create knowledge through interactions between explicit and tacit knowledge. Explicit and tacit knowledge grow in both quality and quantity during the process of converting knowledge. The four modes of converting knowledge are socialisation, externalisation, combination and internalisation (Nonaka 1994).

Socialisation is tacit to tacit knowledge transfer. Because tacit knowledge is difficult to formalise and is often time- and space-specific, one acquires and converts tacit knowledge only through shared experience. Socialisation typically occurs when people share the same environment. Examples include traditional apprenticeships (apprentices acquire the tacit knowledge they need through hands-on experience rather than from written manuals or textbooks) and informal social meetings outside of the workplace (creating and sharing worldviews, mental models and mutual trust). It also occurs outside of organisations' boundaries (acquiring and taking advantage of the tacit knowledge embedded in customers or suppliers) (Nonaka 1994).

Externalisation is tacit to explicit knowledge transfer. Knowledge forms when tacit knowledge articulates into explicit knowledge. This allows others to share it and it then becomes the basis of new knowledge. Tacit knowledge becomes explicit through metaphors, analogies, concepts, hypotheses or models.

An example of externalisation is a quality-control cycle that allows employees to make improvements to manufacturing processes by articulating the tacit knowledge of enterprises that they have accumulated over years on the job (Nonaka 1994).

Combination is transferring explicit knowledge to more complex and systematic sets of explicit knowledge. Explicit knowledge accumulates internally in, or externally from, enterprises and then they combine, edit or process it to form new knowledge. They then disseminate it amongst their members. The creative use of computerised communication networks and large-scale databases can then support the processes.

Examples are collecting and contextualising organisationwide information to form financial reports or breaking down corporate visions into operationalised business or product concepts, where financial reports and operationalised business or product concepts represent new explicit knowledge (Nonaka 1994).

Internalisation is explicit to tacit knowledge transfer, which is similar to 'learning by doing'. Enterprises share the created 
explicit knowledge and employees convert it into tacit knowledge as they embody it. Enterprises have to actualise explicit knowledge through action and practice.

For example, employees read documents or manuals about their jobs and their enterprises and react to the information. Trainees can internalise the explicit knowledge in the documents to enrich their tacit knowledge bases. Employees can also embody explicit knowledge through simulations or experiments that trigger learning by doing.

\section{A knowledge management framework to grow innovation capability maturity}

The aim of the framework (see Figure 1) developed during this study was to investigate organisational support by using business tools to grow innovation capability maturity. The hypothesis was that one could design a knowledge management framework, which would enable growth in innovation capability maturity, by aligning knowledge creation processes to the requirements for moving innovation capability growth from one maturity level to the next.
Consequently, considering the earlier SECI model process descriptions and the descriptions of the generic level of innovation capability maturity detailed earlier, the researchers identified a knowledge-creation path that acts as a key enabler for growth from maturity level 1 to maturity level 5 .

This knowledge-growth path is the cornerstone of the search for a knowledge management framework to grow innovation capability maturity. The researchers identified the requirements for knowledge management tools and organisational facilitating conditions, which support the specific knowledge creation processes (that the identified knowledge-creation path highlights), through an extensive literature study. The researchers chose documents based on:

- whether they, directly or indirectly, could provide the requirements for, or the fundamental factors to consider when, managing knowledge

- whether they focused specifically on managing or facilitating the creation of knowledge that occurs during the processes of socialisation, externalisation, combination and internalisation.

\begin{tabular}{|c|c|c|c|c|c|c|}
\hline \multirow{8}{*}{$\begin{array}{l}\text { ICM } \\
\text { level } \\
\\
\\
\overline{8} \\
\frac{8}{8}\end{array}$} & $\begin{array}{l}\text { Growth requirements } \\
\text { Key knowledge creation path }\end{array}$ & \multirow{8}{*}{ 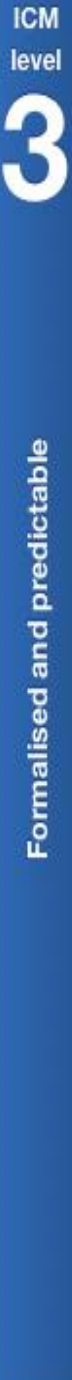 } & \multirow{2}{*}{\multicolumn{2}{|c|}{ 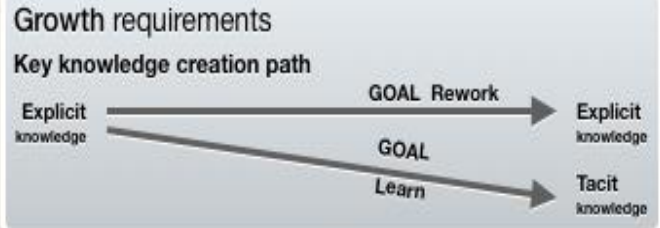 }} & \multirow{8}{*}{ 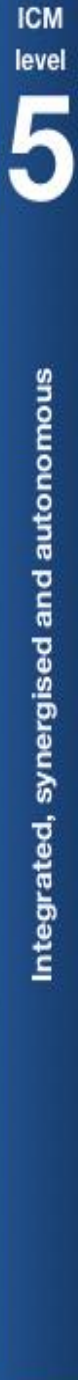 } & 5 \\
\hline & Tacit Cop & & & & & $\begin{array}{l}\text { Growth requirements } \\
\text { Key knowledge creation path }\end{array}$ \\
\hline & $\begin{array}{l}\text { Input requirements } \\
\text { Obtain and convey through } \\
\text { interaction }\end{array}$ & & $\begin{array}{l}\text { Input requirements } \\
\text { Identify, locate, obtain, } \\
\text { integrate }\end{array}$ & \multirow{2}{*}{$\begin{array}{l}\text { Input requirements } \\
\text { Identify, make accessible } \\
\text { in right format } \\
\text { Facilitate a local, decentralised, } \\
\text { self-directed learning } \\
\text { approach. } \\
\text { Comprehensibly structure } \\
\text { knowledge and provide } \\
\text { access to well-structured } \\
\text { knowledge. }\end{array}$} & & $\underset{\text { knowledge }}{\text { Tacit }} \underset{\text { Share }}{\longrightarrow} \underset{\text { Tacit }}{\text { Tenowledge }}$ \\
\hline & $\begin{array}{l}\text { Enable identification of people } \\
\text { (internal and external to the } \\
\text { organisation) with appropriate } \\
\text { knowledge. Enable creation of } \\
\text { dialogue and discussion } \\
\text { opportunities. }\end{array}$ & & $\begin{array}{l}\text { Support a culture that prohibits/ } \\
\text { minimises knowledge hiding } \\
\text { (internal and external to the } \\
\text { organisation) and ensures } \\
\text { unrestricted access. Clear-cut } \\
\text { roles and responsibilities } \\
\text { (i.e. knowledge gatherer) }\end{array}$ & & & \multirow{2}{*}{$\begin{array}{l}\text { Input requirements } \\
\text { Obtain and convey through } \\
\text { interaction } \\
\text { Support direct collaboration } \\
\text { between individuals (internal } \\
\text { and external to the } \\
\text { organisation) within close } \\
\text { personal relationships and } \\
\text { mutual experiences / } \\
\text { common activities. }\end{array}$} \\
\hline & $\begin{array}{l}\text { Output requirements } \\
\text { Transform into }\end{array}$ & & $\begin{array}{l}\text { Output requirements } \\
\text { Disseminate to organise }\end{array}$ & \multirow{2}{*}{$\begin{array}{l}\text { Output requirements } \\
\text { Understand and embody } \\
\text { Support efficient } \\
\text { communication. Balance } \\
\text { phases of ICT-supported } \\
\text { learning with face-to-face } \\
\text { contact and social } \\
\text { geographical closeness. }\end{array}$} & & \\
\hline & $\begin{array}{l}\text { Enable defining of clear-cut } \\
\text { roles and responsibilities. } \\
\text { Allocate enough time to } \\
\text { structure and record } \\
\text { knowledge. }\end{array}$ & & $\begin{array}{l}\text { reapply more effectively } \\
\text { Cultivate a realistic perception } \\
\text { towards potential/limits of ICT. } \\
\text { Clear-cut roles, responsibilities } \\
\text { (i.e. knowledge analyst) }\end{array}$ & & & \multirow{2}{*}{$\begin{array}{l}\text { Output requirements } \\
\text { Disseminate and share } \\
\text { Frequent occurrences of } \\
\text { face-to-face contact. } \\
\text { Intensive communication } \\
\text { between parties (short and } \\
\text { long term). }\end{array}$} \\
\hline & Supporting & & Supporting & \multirow[b]{2}{*}{$\begin{array}{l}\text { Supporting } \\
\text { requirements } \\
\text { Encourage a culture of } \\
\text { experimenting with / } \\
\text { experiencing new knowledge, } \\
\text { facilitate continuous } \\
\text { application/practice of existing } \\
\text { knowledge, and tolerate } \\
\text { failures. Environment } \\
\text { supportive of, and enough } \\
\text { time allocated for, learning. }\end{array}$} & & \\
\hline & $\begin{array}{l}\text { Trust, high degree of } \\
\text { communication, open lines } \\
\text { for communication, personal } \\
\text { relationships, face-to-face } \\
\text { contact, geographical and/or } \\
\text { social closeness, shared } \\
\text { values. }\end{array}$ & & $\begin{array}{l}\text { Positive attitude toward ICT. } \\
\text { High degrees of structure and } \\
\text { formalisation due to possibility } \\
\text { of large geographical } \\
\text { dispersion. }\end{array}$ & & & $\begin{array}{l}\text { Supporting requirements } \\
\text { Direct collaboration between } \\
\text { individuals in a culture of trust, } \\
\text { empathy, openness. Low levels } \\
\text { of lingual and cultural } \\
\text { differences. Geographical and } \\
\text { social closeness. }\end{array}$ \\
\hline
\end{tabular}

Source: Authors' own data

FIGURE 1: Knowledge management framework to grow innovation capability. 
Document selection was also guided by (although not restricted to) author prominence in the field. The result of this investigation was a conceptual framework (see Figure 1) that serves as a guideline for using knowledge management as a vehicle for growing innovation capability maturity.

A descriptive and practical approach to the processes of creating knowledge, especially in order to understand their underlying logic and practical implications, is to see knowledge creation as having an input and output perspective as well as an operational task associated with it (Armistead 1999; Back, Von Krogh, Seufert \& Enkel 2005). For example, the process of internalising would have, as an input, explicit knowledge that one has to find, and tacit knowledge, which one has to learn, as an output.

Consequently, the researchers structured the generic requirements for knowledge management tools and the organisational facilitating conditions that support the specific knowledge creation processes (highlighted in the identified knowledge-creation path) into an input, output and supporting perspective for each process of creating knowledge.

Therefore, the structure of the framework comprises three improvement columns that show the key knowledgecreation path:

- one between innovation capability maturity (ICM) level 1 and level 3 (externalisation)

- one between maturity level 3 and level 5 (combination and internalisation)

- the supporting improvement column (socialisation).

Each improvement column contains four main components:

- an innovation capability maturity growth perspective that shows the key knowledge creation processes enterprises need to enable growth in innovation capability maturity

- a knowledge creation input perspective that gives the main knowledge action and the enabling requirements for knowledge management tools to support the input perspective of the specific process of creating knowledge

- a knowledge creation output perspective that gives the main knowledge action and the enabling requirements for knowledge management tools to support the output perspective of the specific process of creating knowledge

- a knowledge creation supporting perspective that gives the elements that are crucial to the success of the specific process(es) for creating knowledge but which relate more to organisational facilitating conditions than only to the input or output aspects of the process of creating knowledge.

The importance of this framework is that it gives guidelines for using knowledge management as a vehicle for growing innovation capability maturity. In practical terms, the framework aims to provide 'as is' and 'to be' reference points for determining whether enterprises' organisational conditions and business tools are sufficient to sustain or grow their innovation capability maturity.
It is important to note that the framework is simply a tool. As with all tools, its success depends on the knowledge, experience and dedication of the person, project team, department or enterprise that is applying it.

The framework provides a reference point for evaluating enterprises' organisational conditions and business tools in order to sustain innovation capability maturity. If they use the framework, enterprises should be able to answer this question: 'Given our innovation capability maturity level, do our knowledge management-related tools and organisational conditions meet the requirements that will enable us to fulfil our innovation-related activity requirements continuously for this maturity level?'

The framework provides a reference point for benchmarking enterprises' organisational conditions and business tools in order to grow their innovation capability maturity. If they use the framework, enterprises should be able to answer this question: Given our innovation capability maturity level, do our knowledge management-related tools and organisational conditions meet the requirements that will enable us to improve our innovation-related activity requirements for this maturity level and move from our current maturity level to the next?

Enterprises could obtain these indications of their level of innovation capability maturity formally or informally. A formal indication would entail an assessment of innovation capability maturity - throughout the enterprises, per innovation capability area, per innovation capability requirement or through combinations of them. A less formal indication would mean that enterprises simply benchmark their known innovation-related activities against the generic ICMM maturity level descriptions without going through an official assessment.

\section{Evaluating the framework}

Applying the framework practically in real enterprises would prove or disprove the research question, which is whether enterprises can use knowledge management tools and organisational facilitating conditions to enable them to grow their innovation capability maturity.

Unfortunately, this was not possible because one would need anything up to five years or longer to test the framework in practice. Measuring growth in innovation capability maturity takes time, especially when measuring growth through the five maturity phases.

Consequently, the researchers chose five industry and subject theory experts from various fields to evaluate the framework. A limit of the evaluation was that the interviewees could only respond from their own experiences and frames of reference as well as by considering what the researchers presented to them.

The researchers chose a research-evaluation questionnaire and research summary as the ways of facilitating a semi- 
structured interviewing process as well as for discussing the accuracy, applicability and usability of the framework. The questionnaire contained three background contextualisation questions, five framework-specific questions and a section for comments. The researchers chose the questions to cover all aspects of the framework systematically. Their intention was to create a platform for a comprehensive discussion of the research. The researchers began the evaluation process by sending each expert a 14-page research summary with the framework and the research-evaluation questionnaire electronically.

When they received the documents, the experts could work through the research summary and consider the framework in their own time. The time available to the experts determined how they would respond to the researchevaluation questionnaire. Three preferred to give detailed written answers. This reduced the time they had available for interviews. Two experts preferred to use the evaluation questions as a way of preparing for one-on-one discussions of the research with the authors. The evaluation questions provided a background to these discussions, thereby assuring that all the experts had equal platforms from which to evaluate the research.

The goal of each evaluation differed in the sense that each evaluation aimed to assess a different focus of the research. Even though each expert received the same set of evaluation questions, the three written responses provided unique angles to the questions and highlighted the diverse backgrounds of the experts. Similarly, an emphasis on the discussion of the research aspects relevant to the backgrounds of the experts characterised the two interviews.

\section{Background contextualisation questions}

These questions aimed to provide a context for the answers, comments and suggestions the researchers received in response to the framework evaluation. They asked the experts to state their occupations and industries and to explain the extent of their exposure to knowledge management and innovation capability maturity. Table 1 gives an overview of the interviewees' background in the fields of innovation and knowledge management.

\section{Framework-specific questions}

These questions aimed to provide a basis for evaluating the accuracy, applicability and usability of the framework systematically.
The first two questions evaluated the accuracy of the identified knowledge-creation path as a key enabler for movement between levels of innovation capability maturity. They asked the experts whether they agreed with the reasoning applied in identifying this knowledge-growth path. Consequently, the questions explored whether this knowledge-growth path accurately addressed the key maturity level description requirements for moving from one maturity level to the next.

The next two questions evaluated the accuracy of the content of the framework and the logic of its structure. They asked the experts whether they agreed with the specific requirements of the knowledge management tools the framework detailed and whether they agreed with the structure of the framework, synthesised to provide an input, output and supporting perspective to each knowledge creation process in the growth path.

The final framework-related evaluation question aimed at determining the applicability and usability of the framework.

\section{Reasoning applied when identifying the knowledge-growth path}

All the experts agreed with the reasoning applied when the knowledge-creation path was identified as a key enabler of growth in innovation capability maturity. They also thought that this path accurately addressed the key maturity level description requirements for moving from one maturity level to the next.

However, Expert B remarked that 'I would recommend that you make sure to specify that the growth path that you have identified isn't for the whole organisation; just trying to manage it all.' Expert D agreed completely with the specific knowledge-creation path identified as a key enabler of movement between maturity levels. He was also satisfied that this identified path accurately addressed the key maturity level description requirement for moving from one maturity level to the next. Expert E was unsure what the authors meant by the socialisation process: 'Does it imply that it runs across all CMM levels?'

\section{Agreement with the requirements of the knowledge management tools the framework detailed}

Expert A could not find any gaps in the requirements of the specific knowledge management tools and found the

TABLE 1: Interviewees' background in innovation and knowledge management.

\begin{tabular}{|c|c|c|c|c|}
\hline Interviewee & Designation & Industry & Exposure to innovation and capability maturity models & Exposure to knowledge management \\
\hline Expert A & Programme manager & Innovation management consulting & $\begin{array}{l}\text { Extensive knowledge of, and experience in, innovation, } \\
\text { especially innovation capability maturity }\end{array}$ & $\begin{array}{l}\text { Solid background in knowledge } \\
\text { management }\end{array}$ \\
\hline Expert B & Lecturer & Academic or strategic consulting & $\begin{array}{l}\text { Solid knowledge of innovation but limited formal } \\
\text { exposure to capability maturity models }\end{array}$ & $\begin{array}{l}\text { Extensive experience in knowledge } \\
\text { management }\end{array}$ \\
\hline Expert C & Enterprise architect & Professional services industry & Solid knowledge of capability maturity models & $\begin{array}{l}\text { Considerable experience in information } \\
\text { management and experience in } \\
\text { knowledge management }\end{array}$ \\
\hline Expert D & Strategy consultant & $\begin{array}{l}\text { Information technology and } \\
\text { services industry }\end{array}$ & Extensive experience in capability maturity models & $\begin{array}{l}\text { Limited formal exposure to knowledge } \\
\text { management, but practical experience in } \\
\text { how it related to the } \mathrm{CMMI}^{\otimes}\end{array}$ \\
\hline Expert E & General manager & $\begin{array}{l}\text { Mobile telecommunication } \\
\text { industry }\end{array}$ & Experience in capability maturity models & $\begin{array}{l}\text { Solid background in knowledge } \\
\text { management }\end{array}$ \\
\hline
\end{tabular}


structure of the framework clear and concise. He added that 'should these activities, tools, methods, etc. be categorised into the framework, it would provide an easy means for referencing the appropriate mechanisms for the task at hand'. Expert B, Expert C and Expert D agreed with the requirements of the tools the framework detailed and the structure of the framework. Expert D commented that 'this framework is very good, I'm 100\% with you, and I think it's very valuable.' Expert E questioned whether the authors also intended the use of system tools and technology. She agreed with the structure of the framework, but here the uncertainty about the implication of the socialisation process also surfaced: 'I like the framework - only the socialisation component, exactly where it fits in (across 1 to 5 or for 5 only) as described above is not clear to me.' She suggested that the researchers alter the appearance of the framework to show the socialisation process as a line across all the maturity levels and added that it will improve readers' understanding visually.

\section{Applicability and usability of the framework}

Expert A commented that the framework was generic and did not stipulate specific activities, tools or methods but 'should a company go to the effort to select the appropriate tools using the framework and allocate them into the framework, it should be applicable and useful.' He concluded his response by commenting that he would like 'to show appreciation for the seemingly 'simple' framework - it often takes significantly more effort to represent something that is complex in a simple manner while ensuring its accuracy.' Expert B commented:

'Don't get me wrong, I think you've got an excellent thing going here; one of the better, more advanced attempts that I've seen, I'm just afraid that you'll make it too complex ....' (Expert B, lecturer, academic or strategic consulting industry)

Expert $C$ gave a positive response from an applicability and usability perspective: 'I think it's very applicable, and on the right level of detail. I find it practical.' However, he recommended that the researchers take care to present the framework so that is understandable:

'I think the thing about the framework is contextualisation; it can be difficult to explain to someone who doesn't have the same background and level of knowledge of the subject as you have; where it fits in and how it works.' (Expert $C$, enterprise architect, professional services industry)

Expert D noted that 'It is definitely usable and valuable within the context of the ICMM, and I think with a little adaptation, it will be valuable to the CMMI community as well.' Expert E responded very positively:

'The framework is definitely something that I can personally very easily use in my work environment. I would easily be able to translate it to how I can apply it in our organisation. I went through every block in the framework, asking what the input and output was, and how we can support that, and it was very easy for me to make those links; it works very nicely. What was also very interesting was that it enables you to identify gaps; if you for example say 'identify, locate, obtain and integrate', I can for example go and check that, yes, we can identify, locate and obtain, but integration is a bit of an issue; so to use it as a bit of a rough analysis.' (Expert E, general manager, mobile telecommunication industry)

To conclude, the researchers can state that they received no criticism during the evaluation process about the ability of the framework to enable growth in innovation capability maturity and that it was unnecessary to change the framework.

One interviewee commented on the visual effect of the framework and its ability to convey the context of its elements. The interviewee was unsure, at first glance, whether the socialisation process ran across all the levels of innovation capability maturity or whether it was only a supporting process at level 5 .

No other interviewees had a problem with the visual interpretation of the framework. Therefore, the researchers decided to keep the current framework presentation. It was also possible that the researchers could achieve wider applicability if they refined the framework for use in a $\mathrm{CMMI}^{\circledR}$ context, because the $\mathrm{CMMI}^{\circledast}$ is the successor to the $\mathrm{SW}-\mathrm{CMM}^{\circledR}$, the basis for most maturity models in use.

There are a few differences between the ICMM and CMMI ${ }^{\circledR}$. They make the framework this document presents not immediately applicable to the $\mathrm{CMMI}^{\circledR}$ community. These are that the $\mathrm{CMMI}{ }^{\circledR}$ implies that enterprises only need innovation at higher organisational maturity levels. It emerged during the interview process that people who understand the $\mathrm{CMMI}^{\circledR}$ very well would still find the framework useful.

All five experts agreed with the statements that follow:

- the reasoning applied when identifying the specific knowledge creation process path as a key enabler of movement between innovation capability maturity levels is logical and sound

- this path addresses the key requirements for growth from one maturity level to the next accurately

- the requirements of the knowledge management tools and the organisational facilitating conditions the framework details for each identified knowledge creation process in the path are accurate.

Interviews with the five subject matter experts support the hypothesis that one can design a knowledge management framework that enables growth in innovation capability maturity by aligning knowledge creation processes to the requirements for moving from one maturity level to the next.

\section{Conclusion}

There is a gap in the literature on formal guidelines for using business tools to enable growth in innovation capability maturity. This article introduced innovation capability maturity models and discussed the state of capability maturity. It gave reasons why the ICMM is the foundation for further and related discussions on innovation capability maturity. 
The researchers designed a knowledge management framework that enables growth in innovation capability maturity by aligning knowledge creation processes to the requirements for moving from one maturity level to the next. The effect of this framework is that it gives guidelines for using knowledge management as a vehicle for growing innovation capability maturity. The researchers evaluated the ability of the framework to enable growth in innovation capability maturity by using a questionnaire and an interview-based evaluation procedure.

The intention of the framework the article presents is not to be the be-all and end-all solution to enable growth in innovation capability maturity, nor is its intention to provide a step-bystep enterprise-wide knowledge management integration plan. The authors' aim was to investigate organisational support, using business tools, to grow innovation capability maturity. Its unique research contribution lies in that it provides a tangible link between the fields of knowledge management and innovation capability maturity.

A shortcoming of the research is that it did not allow for the practical implementation of the framework. Consequently, five industry and subject experts from various fields evaluated it. The authors received encouraging responses to the practical applicability and usability of the framework from the five interviewees.

The authors suggest that future research should include detailed studies to align the processes for creating knowledge with the requirements for growing innovation capability maturity. Furthermore, the conceptual nature of this research leaves many opportunities for further research into the practical application of the framework because one can only determine the ability of the framework to enable growth in innovation capability maturity via real-world implementation.

Practical implementation would also provide a platform for investigating whether there are gaps in the requirements for knowledge management tools and facilitating conditions and they would indicate the nature of these shortcomings. They could serve as starting points for determining whether future work is necessary to develop an implementation manual and/or an implementation methodology to accompany the framework because the framework is a tool. Its success depends on the knowledge, experience and dedication of the person, project team, department or organisation that will apply it.

This framework is a unique, first conceptual step toward providing knowledge management guidelines to enable growth in innovation capability maturity.

\section{Acknowledgements Competing interests}

The authors declare that they have no financial or personal relationship(s) that may have inappropriately influenced them when they wrote this paper.

\section{Authors' contributions}

D.E. (University of Stellenbosch) made the main conceptual contribution and performed all of the research in this study. C.S. (University of Stellenbosch) and A.D.T. (University of Johannesburg) were the co-supervisors. D.E. (University of Stellenbosch) and A.D.T. (University of Johannesburg) wrote the manuscript.

\section{References}

Accelper Consulting, 2010, Business innovation maturity model, viewed 05 March 2011, from http://accelper.com

Armistead, C., 1999, 'Knowledge management and process performance', Journal of Knowledge Management 3(2), 143-157. http://dx.doi. org/10.1108/13673279910275602

Back, A., Von Krogh, G., Seufert, A. \& Enkel, E., 2005, Putting knowledge networks into action: Methodology, development, maintenance, Springer, Berlin. http://dx.doi. org/10.1007/b138845

Baker, K.A. 2002, 'Management benchmark study, chapter 14: Innovation', viewed 04 May 2011, from http://www.au.af.mil/au/awc/awcgate/doe/benchmark

Calantone, R.J., Cavusgil, S.T. \& Zhao, Y. 2002, 'Learning orientation, firm innovation, capability, and firm performance', Industrial Marketing Management 31(6), 515524. http://dx.doi.org/10.1016/S0019-8501(01)00203-6

Carneiro, A., 2000, 'How does knowledge management influence innovation and competitiveness?', Journal of Knowledge Management 4(2), 87-98. http://dx.doi. org/10.1108/13673270010372242

Cavusgil, S.T., Calantone, R.J. \& Zhao, Y., 2003, 'Tacit knowledge transfer and firm innovation capability', Journal of Business \& Industrial Marketing 18(1), 6-21. http://dx.doi.org/10.1108/08858620310458615

Champlin, B., 2003, Toward a comprehensive data management maturity model (DM3), viewed 06 May 2011, from http://www.powershow.com/view/1f797ZDcxZ/Toward_a_Comprehensive_Data_Management_Maturity_Model_DM3 flash_ppt_presentation

Choo, C.W. \& Bontis, N., 2002, The strategic management of intellectual capital and organizational knowledge, Oxford University Press, New York.

CMMI Product Team, 2002, Capability maturity model integration (CMMI'), Version 1.1, Carnegie-Mellon Software Engineering Institute, Pittsburgh.

Cooke-Davies, T.J., 2004, 'Measurement of organisational maturity: Questions for future research' in Innovations: Project management research, Project Management Institute, Newtown Square, PA.

Darroch, J., 2005, 'Knowledge management, innovation and firm performance', Journal of Knowledge Management 9(3), 101-115. http://dx.doi. org/10.1108/13673270510602809

Davenport, T.H. \& Prusak, L., 2000, Working knowledge: How organizations manage what they know, Harvard Business School Press, Boston, MA.

Degen-Hientz, H., Fäustle, M. \& Hörmann, K., 2005, 'CMMI - An executive summary', viewed 09 October 2010, from www.kuglermaag.com

Du Plessis, M., 2007, 'The role of knowledge management in innovation', Journal of Knowledge Management 11(4), 20-29. http://dx.doi. org/10.1108/13673270710762684

Du Preez, N., Schutte, C., Essmann, H., Louw, L. \& Marais, S., 2009, Enterprise engineering textbook, University of Stellenbosch, Stellenbosch.

Essmann, H.E., 2009, 'Toward innovation capability maturity', PhD Industrial Engineering Thesis, University of Stellenbosch, Stellenbosch.

Fairchild, A.M., 2004, 'Information technology outsourcing (ITO) governance: An examination of the outsourcing management maturity model', in 37th Hawail International Conference on System Sciences, IEEE, Bigh Island, Hawaii, January 05-08, 2004. http://doi.ieeecomputersociety.org/10.1109/HICSS.2004.1265565

Gourlay, S., 2006, 'Conceptualizing knowledge creation: A critique of Nonaka's theory', Journal of Management Studies 43(7), 1415-1436. http://dx.doi.org/10.1111/ j.1467-6486.2006.00637.x

Gray, P., 2000, Knowledge management overview, CRITO working paper, University of California, Irvine, CA.

Hamel, G., 2000, Leading the revolution, Harvard Business School Press, Boston, MA.

INPAQT, 2010, 'INPAQT innovation capability maturity model', viewed 12 May 2011, from www.inpaqt.nl

Katz, B., 2007, 'The integration of project management processes with a methodology to manage a radical innovation project', MSc Industrial Engineering Dissertation, University of Stellenbosch, Stellenbosch, South Africa.

LeVasseur, C., 2000, 'Describing the capability maturity model', in Measure IT, New York, Gartner.

Lin, H., 2007, 'Knowledge sharing and firm innovation capability: an empirical study', International Journal of Manpower 28(3/4), 315-332. http://dx.doi. org/10.1108/01437720710755272 
Moore, G.A., 2005, Dealing with Darwin: How great companies innovate at every phase of their evolution, Penguin Books, London.

Narayana, M.G.P.L., 2005, A framework approach to measure innovation maturity, in Proceedings of the Engineering Management Conference, St John's, Newfoundland, September 11-13.

Neely, A., Filippini, R., Forza, C., Vinelli, A. \& Hii, J., 2001, 'A framework for analysing business performance, firm innovation and related contextual factors: Perception of managers and policy makers in two European regions', Integrated Manufacturing Systems 12(2), 114-124. http://dx.doi.org/10.1108/09576060110384307

Nonaka, I., 1994, 'A dynamic theory of organizational knowledge creation', Organization Science 5(1), 14-37. http://dx.doi.org/10.1287/orsc.5.1.14

OVO, 2010, 'Innovation maturity model', viewed 21 January 2011, from http://www. slideshare.net/jdpuva
Paap, J. \& Katz, R., 2004, 'Anticipating disruptive innovation', Research Technology Management 47(5), 13-22.

PRTM, 2007, 'Innovation maturity model', viewed 04 March 2011 from http://www. innovationtools.com/PDF/Roadmap_PRTM.pdf

Ruggles, R., 1998, 'State of the notion: Knowledge management in practice', California Management Review 40(3), 80-89.

Small, C.T. \& Sage, A.P., 2005/2006, 'Knowledge management and knowledge sharing: a review', Information Knowledge Systems Management 5, 153-169.

The Innovation Practice, 2007, 'Innovation aptitude ${ }^{\top \mathrm{M}}$ audit', viewed 15 December 2010, from www.theinnovationpractice.com

Think For A Change, 2009, 'Innovation maturity model', viewed 21 February 2011, from http://www.thinkforachange.com 